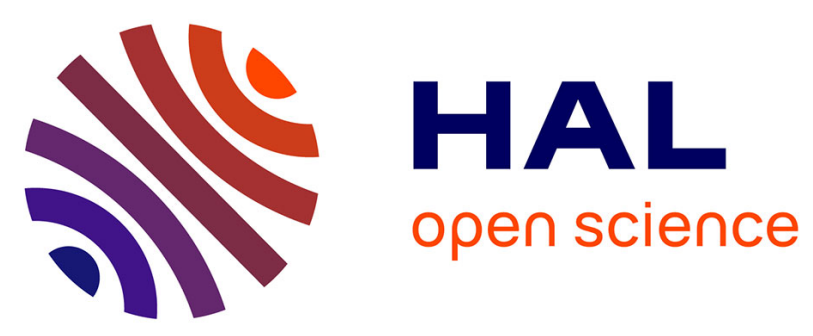

\title{
A comprehensive model of purine uptake by the malaria parasite Plasmodium falciparum: identification of four purine transport activities in intraerythrocytic parasites
}

Neils B. Quashie, Dominique Dorin-Semblat, Patrick G. Bray, Giancarlo A. Biagini, Christian Doerig, Lisa C. Ranford-Cartwright, Harry P. de Koning

\section{To cite this version:}

Neils B. Quashie, Dominique Dorin-Semblat, Patrick G. Bray, Giancarlo A. Biagini, Christian Doerig, et al.. A comprehensive model of purine uptake by the malaria parasite Plasmodium falciparum: identification of four purine transport activities in intraerythrocytic parasites. Biochemical Journal, 2008, 411 (2), pp.287-295. 10.1042/BJ20071460 . hal-00478901

\section{HAL Id: hal-00478901 https://hal.science/hal-00478901}

Submitted on 30 Apr 2010

HAL is a multi-disciplinary open access archive for the deposit and dissemination of scientific research documents, whether they are published or not. The documents may come from teaching and research institutions in France or abroad, or from public or private research centers.
L'archive ouverte pluridisciplinaire HAL, est destinée au dépôt et à la diffusion de documents scientifiques de niveau recherche, publiés ou non, émanant des établissements d'enseignement et de recherche français ou étrangers, des laboratoires publics ou privés. 


\section{A comprehensive model of purine uptake by the malaria parasite Plasmodium falciparum: identification of four purine transport activities in intraerythrocytic parasites.}

4
Neils B. Quashie ${ }^{1}$, Dominique Dorin-Semblat ${ }^{2}$, Patrick G. Bray ${ }^{3}$, Giancarlo A. Biagini ${ }^{3}$, Christian Doerig ${ }^{2}$, Lisa C. Ranford-Cartwright ${ }^{1}$ and Harry P. de Koning ${ }^{1}$

${ }^{1}$ Institute of Biomedical and Life Sciences, Division of Infection and Immunity, Glasgow G12 8TA, UK; ${ }^{2}$ INSERM U609, Wellcome Centre for Molecular Parasitology, Anderson College, 56 Dumbarton Road, Glasgow G11 6NU, UK; ${ }^{3}$ Division of Molecular Biology and Immunology, Liverpool School of Tropical Medicine, Liverpool L3 5QA, UK.

Running head left:

QUASHIE et al

Running head right:

Designation:

PURINE TRANSPORT IN PLASMODIUM

RED CELLS

$\underline{\text { Running title: Purine transport in intraerythrocytic Plasmodium }}$ 


\section{Synopsis}

Plasmodium falciparum is incapable of de novo purine biosynthesis, and is absolutely dependent on transporters to salvage purines from the environment. Only one lowaffinity adenosine transporter has been characterised to date. Here we report a comprehensive study of purine nucleobase and nucleoside transport by intraerythrocytic $P$. falciparum parasites. Isolated trophozoites expressed (a) a high affinity hypoxanthine transporter with a secondary capacity for purine nucleosides, (b) a separate high affinity transporter for adenine (c) a low affinity adenosine transporter and (d) a low affinity/high capacity adenine carrier. Hypoxanthine was taken up with 12-fold higher efficiency than adenosine. Using a parasite clone with a disrupted PfNT1 gene we found that the high affinity hypoxanthine/nucleoside transport activity was completely abolished whereas the low affinity adenosine transport activity was unchanged. Adenine transport was increased, presumably to partly compensate for the loss of the high affinity hypoxanthine transporter. We thus propose a model for purine salvage in $P$. falciparum, based on the highly efficient uptake of hypoxanthine by PfNT1 and a high capacity for purine nucleoside uptake by a lower affinity carrier.

Keywords: Purine salvage; Plasmodium falciparum; nucleobase transporter; Equilibrative Nucleoside Transporter family; drug target; PfNT1.

Short title: purine transporters of Plasmodium falciparum.

Abbreviations used:

ENT, Equilibrative Nucleoside Transporter; hFNT1, human Facilitative Nucleoside Transporter; NPP, New Permeation Pathways; PfADET, Plasmodium falciparum Adenine Transporter; PfLAAT, Plasmodium falciparum Low Affinity Adenosine Transporter; PfNT1, Plasmodium falciparum Nucleoside Transporter 1; PV 


\section{Introduction}

Plasmodium spp. are auxotrophic for purines, as are all other parasitic protozoa studied to date, and require an efficient salvage system for these essential nutrients [1]. Purine salvage may be especially important during the fast dividing intraerythrocytic stages, and it has long been known that Plasmodium trophozoites accumulate some purines very rapidly [1,2]. Tracy and Sherman [2] found that hypoxanthine, adenosine and inosine but not adenine or nucleotides were efficiently taken up by the avian malaria parasite $P$. lophurae. Similarly, the rodent malaria $P$. berghei was reported to have two separate uptake systems for purines: one for adenine and one for adenosine, inosine and hypoxanthine [3]. The study of purine metabolism in the human malaria species $P$. falciparum, however, showed clearly that hypoxanthine was by far the preferred purine source for the parasite, with very high activities of hypoxanthine-guanine phosphoribosyltransferase and inosine phosphorylase but not of adenine phosphoribosyltransferase or adenosine kinase [4]. Adenosine salvage appeared to proceed through rapid deamination to inosine and thence to hypoxanthine [4], and this process mostly occurs extracellularly [5]. This explains the observation of Hansen et al. [3] that inhibition of adenosine deaminase with deoxycoformycin potently reduced $\left[{ }^{3} \mathrm{H}\right]$-adenosine uptake by $P$. berghei. The resulting model of a crucial role for hypoxanthine transport in Plasmodium purine salvage was further validated by the study of Berman et al. [6] who showed that depletion of hypoxanthine from infected erythrocytes by xanthine oxidase reduced $P$. falciparum growth by $\sim 90 \%$.

While hypoxanthine transport clearly plays a pivotal role in an essential function of the malaria parasite, almost all available information on Plasmodium purine transporters concerns uptake of adenosine. Penny et al. [7] injected Xenopus oocytes with mRNA from $P$. falciparum and observed increased uptake of adenosine and hypoxanthine, sensitive to at least partial reciprocal inhibition, demonstrating the presence of at least one transporter capable of recognizing both substrates. Two groups have independently cloned the same P. falciparum gene of the Equilibrative Nucleoside Transporter family, which they termed PfENT1 or PfNT1, respectively $[8,9]$, and the PfNT1 protein was found to be localised in the parasite's plasma membrane [10]. Both groups expressed the cloned transporter in Xenopus oocytes for characterization, but they arrived at strikingly different conclusions. Carter et al. [9] described PfNT1 as a broad specificity nucleoside transporter of moderately high affinity for adenosine and inosine and no affinity for nucleobases. In contrast, Parker et al. [8] report a purine nucleoside/nucleobase transporter with a similar, but low, affinity for adenosine, adenine and hypoxanthine. The presence of a low affinity adenosine transporter was recently confirmed by Downie et al. [11] using $P$. falciparum trophozoites isolated after treatment with saponin. On the basis of the adenosine $\mathrm{K}_{\mathrm{m}}$ value, they concluded that this activity must be PfNT1, and this seemed to be confirmed by expression of PfNT1 in oocytes, which revealed a low affinity nucleoside transporter. However, in the current manuscript we will demonstrate conclusively that the low affinity adenosine transporter is not encoded by PfNT1.

Studies to date have not investigated the possibility of a very high affinity purine transporter, such as found in other intracellular [12-14] and extracellular $[15,16]$ protozoan parasites. However, a recent report [17] did strongly suggest that PfNT1 must encode a high affinity purine transporter, as wild-type $P$. falciparum were able to grow in very low levels of purines, but $\triangle P f N T 1$ parasites grew only in $>10 \mu \mathrm{M}$ hypoxanthine, adenosine or inosine. The same study also showed that, at $1 \mu \mathrm{M}$ 
concentrations, accumulation of those three purines was reduced in $\triangle P f N T 1$ but the characteristics of this transporter in terms of substrate affinity and specificity was not further investigated.

We report here the first systematic study of high affinity hypoxanthine, adenine and adenosine transport activities in $P$. falciparum trophozoites. We have identified and characterised a broad-specificity carrier that transports hypoxanthine, guanine, adenosine, guanosine and inosine, but not for adenine. In addition we characterised a low affinity adenosine transporter (which we denote PfLAAT) and a high affinity adenine transporter (denoted PfADET1) and demonstrate the existence of a further low affinity uptake route for adenine (PfADET2). To confirm our hypothesis that the high affinity transport activity is encoded by the previously reported PfNT1, we generated a mutant parasite clone with a disrupted PfNT1 gene, designated $\triangle P f n t 1^{\mathrm{GU}}$ to distinguish itself from the clone generated by E1 Bissati et al. [17]. $\Delta P f n t 1^{\mathrm{GU}}$ had completely lost both the high affinity adenosine uptake capacity and over $85 \%$ of hypoxanthine uptake, while low affinity adenosine uptake was unchanged and high affinity adenine uptake was slightly increased. We therefore conclude that PfNT1 encodes a high affinity hypoxanthine/purine nucleoside transporter.

We present for the first time a comprehensive model of purine uptake by $P$. falciparum, in which the intraerthrocytic stages express at least four distinct purine transport activities. This model finally identifies the biochemical and genetic basis for the parasite's overwhelming reliance on hypoxanthine salvage as its main purine source and is in line with a recent analysis of the $P$. falciparum permeome that showed the presence of four genes of the Equilibrative Nucleoside Transporter (ENT) family in its genome [18]. This family includes all protozoan purine transporters known to date [1]. 
123

124

125

126

127

128

129

130

131

132

133

134

135

136

137

138

139

140

141

142

143

144

145

146

147

148

149

150

151

152

153

154

155

156

157

158

159

160

161

162

163

164

165

166

167

168

169

170

171

172

\section{Experimental}

Plasmodium lines, human cells and chemicals.

All transport experiments were performed with the standard 3D7 drug sensitive laboratory clone of Plasmodium falciparum, originally obtained from David Walliker, University of Edinburgh, UK. Human blood and serum used for Plasmodium culture was obtained from the Glasgow and West of Scotland Blood Transfusion Service. Standard chemicals including purines and pyrimidines were obtained from Sigma and of the highest purity available. The purine analogues JA-23 (2-Amino- $\mathrm{N}^{6}$-amino- $\mathrm{N}^{6}$ methyladenosine), JA-24 (2-Amino- $\mathrm{N}^{6}$-amino-adenosine) and JA-32 ( $\mathrm{N}^{6}$-Hydroxy9H-purin-6-amine) were kindly donated by Daniel Brown and David Loakes of the MRC Laboratory of Molecular Biology, Cambridge, UK.

\section{Culturing of $\boldsymbol{P}$. falciparum for transport assays}

Asexual parasites of $P$. falciparum were maintained in continuous culture using slightly modified standard methods [19]. Briefly, parasites were grown in RPMI 1640 medium supplemented with $5.94 \mathrm{~g} / \mathrm{l}$ HEPES, $0.21 \% \mathrm{NaHCO}_{3}$ and $10 \%$ heatinactivated normal human serum at 5\% haematocrit. The culture was incubated at 37 ${ }^{\circ} \mathrm{C}$ under a gas mixture of $1 \% \mathrm{O}_{2}, 3 \% \mathrm{CO}_{2}, 96 \% \mathrm{~N}_{2}$ and medium was changed daily. Parasitaemia of the culture was routinely maintained below 5\%, unless otherwise stated. Prior to use in experiments, parasite cultures were synchronised using a previously described method [20]. Transport experiments were performed with cultures of parasitaemia between 7 and $10 \%$ in order to maximise yield.

\section{Saponin permeabilization of $\boldsymbol{P}$. falciparum-infected erythrocytes}

Permeabilised P. falciparum-infected erythrocytes were prepared by incubating parasitised red blood cells with $0.15 \%(\mathrm{w} / \mathrm{v})$ saponin as described [21]. Briefly, the culture was centrifuged at $600 \times g$ and the supernatant removed. The cell pellets were re-suspended in 5 volumes of $0.15 \%(\mathrm{w} / \mathrm{v})$ saponin in phosphate-buffered saline (137 $\mathrm{mM} \mathrm{NaCl}, 27 \mathrm{mM} \mathrm{KCl}, 1.76 \mathrm{mM} \mathrm{K}_{2} \mathrm{HPO}_{4}, 8 \mathrm{mM} \mathrm{Na}_{2} \mathrm{HPO}_{4}$ ) for one minute. The freed parasites were washed three times with purine-free RPMI 1640 culture medium without serum, and resuspended in the same medium. Parasitaemia was determined by microscopical examination of thin blood smears stained with Giemsa's stain, and red cell density was estimated using a Neubauer counting chamber.

\section{Transport assays with saponin-permeabilised Plasmodium falciparum- infected erythrocytes}

Transport assays were performed with synchronised cultures in the trophozoite stage. After permeabilisation of the erythrocytes with saponin [22], which leaves the parasite plasma membrane intact $[23,24]$, the cells were resuspended in purine-free RPMI 1640 at a concentration of $5 \times 10^{8}$ cells $/ \mathrm{ml}$. Uptake of $\left[{ }^{3} \mathrm{H}\right]$-hypoxanthine (GE Healthcare, $31 \mathrm{Ci} / \mathrm{mmol}$ ), $\left[{ }^{3} \mathrm{H}\right]$-adenosine (GE Healthcare, $16.0 \mathrm{Ci} / \mathrm{mmol}$ ), or $\left[{ }^{3} \mathrm{H}\right]$ adenine (Perkin-Elmer, $32.2 \mathrm{Ci} / \mathrm{mmol}$ ) by P. falciparum trophozoites was measured using a rapid stop/spin method essentially as described previously for Trypanosoma brucei [25], Leishmania spp [14,26], Toxoplasma gondii [13] and human erythrocytes [27]. Transport was measured either at various time intervals to generate plots of uptake rate versus time, or over fixed time intervals in the presence of variable inhibitor concentrations to generate plots for the determination of $\mathrm{K}_{\mathrm{m}}$ and $\mathrm{K}_{\mathrm{i}}$ values, using non-linear regression (GraphPad Prism version 4). Briefly, equal volumes of a suspension of permeabilised-infected erythrocytes and a radiolabeled permeant at 
173

174

175

176

177

178

179

180

181

182

183

184

185

186

187

188

189

190

191

192

193

194

195

196

197

198

199

200

201

202

203

204

205

206

207

208

209

210

211

212

213

214

twice its final concentration (as well as inhibitor at $2 \times$ concentration, where applicable) were mixed for a predetermined time. Influx of permeant into the cells was terminated by adding $1 \mathrm{ml}$ ice-cold stop solution (unlabelled permeant at saturating concentrations) and immediately pelleting the cells by centrifugation at $13,000 \times g$ in a microfuge through an oil-mix $(300 \mu 1$ of 5 parts dibutylphthalate (Aldrich):4 parts dioctylphthalate (Aldrich), v/v), thus preventing further uptake of permeant, which remains in the aqueous layer. Non-mediated influx of the respective permeant was assessed by determining the rate of uptake of the radiolabelled permeant in the presence of a saturating concentration of unlabelled permeant at both room temperature and $0{ }^{\circ} \mathrm{C}$.

The parasite pellets were processed after the uptake using the method previously described by Saliba et al [28], with a slight modification. The aqueous phase was removed by aspiration and the inside walls of the tube carefully washed with distilled water. The water was aspirated out, followed by the oil-mix, and the inside of the tube wiped with folded tissue paper. The cells were resuspended in 200 $\mu 1$ of $1 \%$ Triton X-100 in water ( $/ \mathrm{v})$ for 10 minutes at room temperature and proteins were precipitated with $200 \mu \mathrm{l}$ of $5 \%$ trichloroacetic acid (TCA). The mixture was finally centrifuged for 7 minutes at $13000 \times g$ and the supernatant transferred into a scintillation vial and mixed with $3.5 \mathrm{ml}$ scintillation fluid (OptiPhase HiSafe, Perkin Elmer). Radioactivity was determined with a Perkin-Elmer 1450 Microbeta Wallac Trilux liquid scintillation counter. All uptake experiments were performed in triplicate.

For any given permeant, the linear phase of uptake was first determined, with a constant permeant concentration incubated for various times to generate a plot of uptake versus time. Linearity was assessed using linear regression and defined as a correlation coefficient $>0.95$ and significant difference from zero uptake (F-test; GraphPad Prism version 4). When uptake was too rapid to obtain linearity of transport at room temperature, this was reassessed at $6{ }^{\circ} \mathrm{C}$ using a ThermoStat plus (Eppendorf, Germany), as indicated in Results. Inhibition studies were always performed well within the linear phase of uptake, and thus reflect true initial rates of transport across the $P$. falciparum plasma membrane rather than rates of metabolism or sequestration.

\section{Generation of Plasmodium falciparum clones with disrupted PfNT1}

Our strategy for knocking-out the Plasmodium gene PfNT1 relies on single crossover homologous recombination and full details of the methods are provided in the on-line data supplement. Briefly, a plasmid was constructed containing the central sequence of PfNT1 spanning the predicted transmembrane domains 3-6 and part of transmembrane domain 2 . The construct was used to transfect $P$. falciparum parasites of clone 3D7 using standard methods [29], with control parasites treated similarly but with no construct present during electroporation. Transformed parasites were selected with blasticidin and cloned. Successful disruption of the gene was confirmed using PCR and Southern blot as described in the data supplement. 


\section{Results and Discussion}

\section{High affinity hypoxanthine transport in $P$. falciparum trophozoites}

In order to study the transporters in the plasma membrane of $P$. falciparum, infected human erythrocytes were permeabilised with saponin, after which the erythrocyte plasma membrane ceases to be a barrier to the passage of solutes [22] but the parasite membranes are not significantly affected by this saponin treatment protocol $[23,24]$. The parasitophorous vacuole membrane remains but this membrane is intrinsically permeable to small solutes [30]. Therefore, initial rates of transport measured in this system reflect uptake by the Plasmodium-encoded transporters located in the parasite's plasma membrane.

Uptake of $0.25 \mu \mathrm{M}$ or $0.1 \mu \mathrm{M}\left[{ }^{3} \mathrm{H}\right]$-hypoxanthine followed a hyperbolical curve, which was linear for up to $120 \mathrm{~s}$ at $20^{\circ} \mathrm{C}$, with a rate of $0.62 \pm 0.04$ and $0.40 \pm$ 0.03 pmol $\left(10^{7} \text { cells }\right)^{-1} \mathrm{~s}^{-1}$, respectively, and was completely inhibited by $1 \mathrm{mM}$ hypoxanthine (Figure 1A). The hypoxanthine thus accumulated would, in the absence of metabolism, reach very high intracellular concentrations: based on an intracellular volume of $2.8 \times 10^{-7} 1 / 10^{7}$ parasites isolated by saponin treatment [28] uptake of 0.25 $\mu \mathrm{M}$ hypoxanthine would be over 1000 -fold concentrated in the parasite - reaching a level of $260 \mu \mathrm{M}$ in 2 minutes. Transport rates remained constant during this time (i.e. linear phase of uptake) because the rate of metabolism was greater than the rate of transport, making transport the rate-limiting step. Alternatively, high affinity purine transport in $P$. falciparum may be energy-dependent, as it is in other protozoan species [31,16,25], allowing uptake against a concentration gradient - but this possibility was not further investigated in this study.

Determining $\left[{ }^{3} \mathrm{H}\right]$-hypoxanthine transport at sub-micromolar concentrations revealed a very high affinity transporter for oxopurines, with a mean $\mathrm{K}_{\mathrm{m}}$ value for hypoxanthine of $0.34 \pm 0.05 \mu \mathrm{M}(\mathrm{n}=6$; Figure $1 \mathrm{~B}$, inset $)$, a $\mathrm{V}_{\max }$ of $0.36 \pm 0.12$ $\operatorname{pmol}\left(10^{7} \text { cells }\right)^{-1} s^{-1}(n=6)$ and a mean $K_{i}$ value of $0.11 \pm 0.01 \mu \mathrm{M}$ for guanine $(n=3)$. In addition, the nucleosides adenosine (Figure 1B), inosine and guanosine displayed affinity in the low micromolar range (Table 1). This hypoxanthine transporter with high affinity for purine nucleosides was designated Plasmodium falciparum Nucleoside Transporter 1 (PfNT1) based on our later observations linking the PfNT1 gene to this transport activity (see "Purine transport in the $\Delta p f n t 1^{\mathrm{GU}}$ clone").

PfNT1 exhibited low affinity for pyrimidines. Only uridine, uracil and thymidine inhibited transport of $30 \mathrm{nM}\left[{ }^{3} \mathrm{H}\right]$-hypoxanthine significantly, at a concentration of $1 \mathrm{mM}$ inhibitor, by $36 \pm 9 \%(\mathrm{P}<0.05), 49 \pm 6 \%(\mathrm{P}<0.01)$ and $57 \pm$ $6 \%(\mathrm{P}<0.02)$ respectively (Paired Student's $t$-test against no-inhibitor control, based on four independent experiments in duplicate). Cytosine, thymine and cytidine (up to $1 \mathrm{mM}$ ) did not significantly inhibit $30 \mathrm{nM}\left[{ }^{3} \mathrm{H}\right]$-hypoxanthine transport (data not shown). This result is not surprising, in the light of the well-documented inability of Plasmodium spp to salvage preformed pyrimidine nucleobases and nucleosides $[1,32]$.

Of all the natural purines tested, only adenine had very little effect on transport of $\left.0.03 \mu \mathrm{M}{ }^{3} \mathrm{H}\right]$-hypoxanthine, with less than $50 \%$ inhibition at $1 \mathrm{mM}$. However, the antiplasmodial adenine analogue JA-32 [33] displayed a $\mathrm{K}_{\mathrm{i}}$ value of $14 \pm 3 \mu \mathrm{M}$ (Fig. $1 \mathrm{~B}$ ), probably as a result of its 'hypoxanthine-like' conformation (i.e. lactam hydrogen on $\mathrm{N} 1$ and $\mathrm{H}$-bond acceptor at the $\mathrm{N}^{6}$ position, see figure $1 \mathrm{~B}$ ). Two $\mathrm{N}^{6}$ substituted adenosine analogues, JA-23 and JA-24, with antiplasmodial activities in the low micromolar range [33], had little $\left(\mathrm{K}_{\mathrm{i}}=320 \pm 80 \mu \mathrm{M}\right.$ for JA-24) or no effect (JA23) on high affinity hypoxanthine transport (not shown). 

The transporter appeared to display a preference for oxopurine nucleobases
over aminopurine bases whereas this preference appears to be curiously absent in the binding of nucleosides: e.g. guanine is the highest affinity nucleobase whereas guanosine is the lowest affinity purine nucleoside (Table 1). Two testable hypotheses may be proposed to explain this apparent paradox: (i) the nucleosides are not actually substrates, but allosteric inhibitors of hypoxanthine transport, or (ii) the nucleosides and nucleobases assume a different orientation within the binding pocket, due to the presence of the ribose moiety. In order to distinguish between these alternatives, we assessed the uptake of low concentrations of $\left[{ }^{3} \mathrm{H}\right]$-adenosine.

\section{High affinity adenosine transport in $\boldsymbol{P}$. falciparum trophozoites}

Uptake of $0.25 \mu \mathrm{M}\left[{ }^{3} \mathrm{H}\right]$-adenosine proceeded with a rate of $0.015 \pm 0.002 \operatorname{pmol}\left(10^{7}\right.$ cells) ${ }^{-1} \mathrm{~s}^{-1}$ over the linear phase (at least $30 \mathrm{~s}$ ), and was completely inhibited by $1 \mathrm{mM}$ adenosine (see figure S1 of the supplementary material). At the end of linear phase, cells had transported approx. 0.55 pmol $\left[{ }^{3} \mathrm{H}\right]$-adenosine $/ 10^{7}$ cells, which would correspond to $\sim 8$-fold the extracellular concentration if unmetabolised. Both the rate of uptake and the level of concentration of adenosine were much less than for hypoxanthine.

Uptake of $0.25 \mu \mathrm{M}\left[{ }^{3} \mathrm{H}\right]$-adenosine was potently inhibited by hypoxanthine (mean $\mathrm{K}_{\mathrm{i}}=0.75 \pm 0.18 \mu \mathrm{M} ; \mathrm{n}=3$ ) and unlabelled adenosine, but only by very high concentrations of adenine (Figure 2). Over three separate experiments, the average of the extrapolated values for an adenine $\mathrm{IC}_{50}$ value would be $\sim 1 \mathrm{mM}$ - three orders of magnitude lower affinity than for hypoxanthine. In the same three experiments, the inhibition by hypoxanthine was not quite complete at $100 \mu \mathrm{M}(6.1 \pm 0.2 \% ; \mathrm{P}<0.05$, paired Student's t-test), possibly the result of a minor contribution to $0.25 \mu \mathrm{M}\left[{ }^{3} \mathrm{H}\right]$ adenosine flux from a second, low affinity adenosine transporter, that is insensitive to hypoxanthine (see "Low affinity transport of $\left[{ }^{3} \mathrm{H}\right]$-adenosine in $P$. falciparum trophozoites"). The mean $\mathrm{K}_{\mathrm{m}}$ for adenosine on the high affinity transporter was determined to be $2.0 \pm 0.2 \mu \mathrm{M}$ and the $\mathrm{V}_{\max }$ as $0.18 \pm 0.08 \operatorname{pmol}\left(10^{7} \text { cells }\right)^{-1} \mathrm{~s}^{-1}(\mathrm{n}=3$; Figure 2 , inset). The strikingly similar reciprocal $K_{m}$ and $K_{i}$ values for adenosine and hypoxanthine uptake are consistent with high affinity uptake of both hypoxanthine and adenosine by PfNT1. However, the $\mathrm{V}_{\max } / \mathrm{K}_{\mathrm{m}}$ ratio indicates an 11.9-fold higher efficiency of translocation for hypoxanthine compared to adenosine, consistent with the preference for hypoxanthine for optimal growth in vitro.

The different selectivity for aminopurine nucleobases and nucleosides noted in the previous section thus seems to indicate that nucleobases and nucleosides orient differently in the same binding site and the kinetic profiles presented here are consistent with competitive inhibition (Figures $1 \mathrm{~B}$ and 2). There are precedents for this; for instance, there is good evidence for different binding orientations for xanthine and uric acid in the Aspergillus nidulans UapA purine transporter [34].

\section{Uptake of $\left[{ }^{3} \mathrm{H}\right]$-adenine is mediated by a separate high affinity transporter}

At $1 \mu \mathrm{M}$ of $\left[{ }^{3} \mathrm{H}\right]$-adenine, uptake was $0.0091 \pm 0.0025 \mathrm{pmol}\left(10^{7} \text { cells }\right)^{-1} \mathrm{~s}^{-1}$ over the linear phase $\left(6 \mathrm{~s} ; \mathrm{r}^{2}=0.93\right)$ and mostly inhibited by $1 \mathrm{mM}$ unlabelled adenine (data not shown). At $120 \mathrm{~s}$ the accumulation ratio (intracellular/extracellular radiolabel concentration based on the intracellular volume of $2.8 \times 10^{-7} 1 / 10^{7}$ parasites cited above) had reached $\sim 0.6$, consistent with an equilibrative process and at best a slow rate of metabolism or no metabolism at all. We tentatively designate this novel 
313 transport activity Plasmodium falciparum adenine transporter 1 (PfADET1), pending

314 the identification of the encoding gene.

315

316

317

318

319

320

321

322

323

324

325

326

327

328

329

330

331

332

333

334

335

336

337

338

339

340

341

342

343

344

345

346

347

348

349

350

351

352

353

354

355

356

357

358

359

360

361

362

In order to determine the $\mathrm{K}_{\mathrm{m}}$ value for this high affinity transporter, uptake of adenine was assessed at $50 \mathrm{nM}$ of radiolabel. Uptake was linear and did not reach equilibrium for up to $240 \mathrm{~s}$ (accumulation ratio was 0.65) (Figure 3A). This allowed inhibition experiments at an incubation time of $150 \mathrm{~s}$, although it was clear that there was a small uptake component that was not sensitive to $1 \mathrm{mM}$ adenine (Figure $3 \mathrm{~A}$ ) possibly resulting from the presence of a very low affinity transporter. Adenine transport was not inhibited by the oxopurines hypoxanthine (Figure $3 \mathrm{~B}$ ), guanine and inosine (not shown), though it was sensitive to adenosine, with a $\mathrm{K}_{\mathrm{i}}$ value of $2.0 \pm 0.2$ $\mu \mathrm{M}$ (Figure 3B). The sub-micromolar $\mathrm{K}_{\mathrm{m}}$ value, similar to the hypoxanthine $\mathrm{K}_{\mathrm{m}}$ for PfNT1, and very low $\mathrm{V}_{\max }$ (Figure 3B), make PfADET1 a high affinity but low capacity transport system with a maximum uptake rate $2-3$ orders of magnitude lower than that measured for high affinity transport of hypoxanthine and adenosine (Table 1).

\section{A very low affinity/high capacity transporter of adenine}

As the uptake of $0.05 \mu \mathrm{M}\left[{ }^{3} \mathrm{H}\right]$-adenine was consistently not fully inhibited by $1 \mathrm{mM}$ unlabelled adenine (previous section) we investigated the possible presence of a lowaffinity adenine transport activity in saponin-isolated $P$. falciparum trophozoites. Uptake of $10 \mu \mathrm{M}\left[{ }^{3} \mathrm{H}\right]$-adenine was linear for up to $12 \mathrm{~s}$, with a rate of $0.13 \pm 0.01$ pmol $\left(10^{7} \text { cells }\right)^{-1} \mathrm{~s}^{-1}\left(\mathrm{r}^{2}=0.96\right)$, reaching an accumulation ratio of 0.85 in $30 \mathrm{~s}$. This could not be entirely attributed to simple diffusion as it was partly inhibited $(\sim 60 \%)$ by $1 \mathrm{mM}$ adenine (Figure S2A, supplementary material). Attempts to establish a $\mathrm{K}_{\mathrm{m}}$ value for $\left[{ }^{3} \mathrm{H}\right]$-adenine uptake on this transporter were unsuccessful - due in part to the high rate of diffusion of adenine at high concentrations, as reported for the related apicomplexan parasite Toxoplasma gondii [13], and because the limitations of adenine solubility prevented the determination of a complete inhibition curve (Figure S2B, supplementary material). However, the $\mathrm{K}_{\mathrm{m}}$ for adenine was estimated to be approximately $1 \mathrm{mM}$, and the $\mathrm{K}_{\mathrm{i}}$ value for adenosine $>2.5 \mathrm{mM}$. There was no clear inhibition by up to $1 \mathrm{mM}$ hypoxanthine (data not shown). This observation, and the fact that these experiments were carried out at $10 \mu \mathrm{M}\left[{ }^{3} \mathrm{H}\right]$ adenine - which fully saturates PfADET1 - as well as the low affinity for adenosine, clearly shows that this adenine transport phenomenon must be mediated by a low affinity transporter separate from either PfNT1 or PfADET1. The low affinity adenine transport activity was provisionally designated PfADET2.

Despite the presence of two adenine transporters, it is not at all clear whether adenine salvage is important to Plasmodium spp and there is considerable controversy about whether Plasmodium can utilise adenine at all, as several groups report the inability to identify genes encoding adenine phosphoribosyltransferase (APRT) and methylthioadenosine phosphorylase in any Plasmodium species [35,36] nor is there any evidence for the activity of adenine deaminase [35]. Yet, the characterisation of APRT from $P$. chabaudi and $P$. falciparum have been reported [37,38]. In addition, $P$. falciparum is reportedly able to grow in vitro on adenine as sole purine source [39] and $P$. knowlesi incorporated adenine into nucleic acids [32]. Although these latter observations could be explained by conversion of the adenine to hypoxanthine in the host cell, Van Dyke reported that the free parasite can also incorporate adenine into nucleic acids, albeit at $1 \%$ of the efficiency by which hypoxanthine is incorporated [40]. The report here of uptake of adenine by P. falciparum trophozoites, however inefficient, would be compatible with the view that adenine can be utilised in some 
363

364

365

366

367

368

369

370

371

372

373

374

375

376

377

378

379

380

381

382

383

384

385

386

387

388

389

390

391

392

393

394

395

396

397

398

399

400

401

402

403

404

405

406

407

408

409

410

411

way but is unlikely to play any major role in the synthesis of nucleotides. It is conceivable that the parasite has a different use for low levels of adenine, which it cannot generate itself from other purines [35], or that adenine at high concentrations could be deaminated by adenosine deaminase.

\section{Low affinity transport of $\left[{ }^{3} \mathrm{H}\right]$-adenosine in $P$. falciparum trophozoites}

Several groups have reported a much lower affinity adenosine transport process than the $\mathrm{K}_{\mathrm{m}}$ value reported here for PfNT1 [8, 9, 11]. We therefore decided to reinvestigate the presence of such a transporter and found that $25 \mu \mathrm{M}\left[{ }^{3} \mathrm{H}\right]$-adenosine is extremely rapidly taken up at room temperature $\left(22{ }^{\circ} \mathrm{C}\right)$ (see Figure S3A, supplementary data), as reported by Downie et al. [11], reaching an accumulation ratio of $\sim 0.6$ by $30 \mathrm{~s}$. We therefore conducted our experiments at $6{ }^{\circ} \mathrm{C}$ and consistently found that uptake of 25 $\mu \mathrm{M}\left[{ }^{3} \mathrm{H}\right]$-adenosine was linear over a period of $4-6 \mathrm{~s}$ at this temperature (see Figure $\mathrm{S} 3 \mathrm{~B}$, supplementary data), and that initial rates of transport could therefore be assessed over a three second interval. At $22{ }^{\circ} \mathrm{C}, 10^{\circ} \mathrm{C}$ or $6{ }^{\circ} \mathrm{C}$ we found that transport was saturable by $1 \mathrm{mM}$ unlabelled adenosine, although this never inhibited fully $100 \%$ of transport (Figures 4 and S3), reflecting the low affinity of this transporter for the substrate. At $6{ }^{\circ} \mathrm{C}$ the rate of uptake of $25 \mu \mathrm{M}\left[{ }^{3} \mathrm{H}\right]$-adenosine was $0.041 \pm 0.004$ pmol $\left(10^{7} \text { cells }\right)^{-1}$. The mean $\mathrm{K}_{\mathrm{m}}$ value under these conditions was $197 \pm 20 \mu \mathrm{M}$, with a $\mathrm{V}_{\max }$ of $0.19 \pm 0.03 \mathrm{pmol}\left(10^{7} \text { cells }\right)^{-1} \mathrm{~s}^{-1}(\mathrm{n}=3$; Figure 4$)$. This transporter was not sensitive to the nucleoside transport inhibitor dipyridamole at concentrations up to 25 $\mu \mathrm{M}$ (data not shown). We have designated this activity the P. falciparum Low Affinity Adenosine Transporter (PfLAAT).

These observations are entirely consistent with the only other characterisation of adenosine transport in P. falciparum trophozoites, by Downie et al. [11]. They reported a low affinity adenosine transporter that mediated uptake of adenosine, inosine and thymidine very quickly, equilibrating within seconds, and insensitive to dipyridamole.

\section{Disruption of the PfNT1 gene.}

In order to gain insight into the possible role of PfNT1 in purine salvage, a parasite line with a disrupted locus was generated. Single crossover homologous recombination at the PfNT1 locus was expected to generate a pseudodiploid configuration, with both truncated copies lacking some of the transmembrane domains of the protein predicted to be essential for the function of the protein (Supplementary data; Figure S4). As the parasite is haploid and PfNT1 is a single copy gene, only one round of drug selection is necessary to obtain a null-mutant. Four parasite clones, denoted B11, D6, B7 and B9, were obtained, and successful disruption of the PfNT1 gene was verified in each clone by PCR and by Southern blot (Figures S5 and S6, supplementary data). The mutant PfNT1 clones were designated $\Delta p f n t 1^{\mathrm{GU}}$, in order to distinguish them from the independently derived $\Delta p f n t 1$ clone of El Bissati et al. [17].

\section{Purine transport in the $\Delta p f n t 1^{\mathrm{GU}}$ clone.}

We next determined the purine uptake profile in $\Delta p f n t 1^{\mathrm{GU}}$ clone D6, using as controls untransformed parasites (wild-type) that had undergone the same procedures. The transport assays were performed simultaneously on both clones, to assess which, if any, of the above identified purine transport activities was affected in the parasites with the disrupted gene. Uptake of $25 \mu \mathrm{M}\left[{ }^{3} \mathrm{H}\right]$-adenosine at $6{ }^{\circ} \mathrm{C}$ was not affected by the disruption of PfNT1, and identical rates of uptake were measured in the two lines: 
$4120.069 \pm 0.05$ and $0.070 \pm 0.07 \operatorname{pmol}\left(10^{7} \text { cells }\right)^{-1} \mathrm{~s}^{-1}$ for $\Delta p f n t 1^{\mathrm{GU}}$ and control, 413 respectively (Figure 5A).

414 In contrast, in several experiments uptake of $0.25 \mu \mathrm{M}\left[{ }^{3} \mathrm{H}\right]$-adenosine was 415 reduced by $97-100 \%$ in $\Delta p f n t 1^{\mathrm{GU}}(\mathrm{n}=3$; Figure $5 \mathrm{~B})$, clearly indicating the loss of 416 high-affinity transport in the mutant line. Similarly, uptake of $0.4 \mu \mathrm{M}\left[{ }^{3} \mathrm{H}\right]-$ 417 hypoxanthine over $120 \mathrm{~s}$ was reduced by $82-98 \%(\mathrm{n}=3$; Figure $5 \mathrm{C})$. The small 418 residual hypoxanthine transport leads us to speculate that a low-affinity hypoxanthine 419 activity might also be expressed in P. falciparum. This would be consistent with the 420 observation of El Bissati et al. [17] that $\Delta p f n t 1 P$. falciparum are able to grow in the 421 presence of high concentrations of hypoxanthine but not in low concentrations.

Transport rates of $1 \mu \mathrm{M}\left[{ }^{3} \mathrm{H}\right]$-adenine were not affected in the $\triangle P f N T 1$ parasites: the initial rates of transport over $12 \mathrm{~s}$ were not significantly different in the $\Delta p f n t 1^{G U}$ line and control cells $(\mathrm{n}=3$; Paired t-test, $\mathrm{P}>0.05)$ (Figure $5 \mathrm{D}$ and inset). However, in three independent experiments the maximum level of $\left[{ }^{3} \mathrm{H}\right]$-adenine transport in the $\Delta p f n t 1^{G U}$ line was double that of the control $(0.16 \pm 0.06$ vs $0.077 \pm$ $0.022 \operatorname{pmol}\left(10^{7} \text { cells }\right)^{-1} \mathrm{~s}^{-1} ; \mathrm{n}=3$, non-linear regression $)$. Rather than upregulation of the transporter we believe this may reflect an increased rate of adenine metabolism in the absence of a source for hypoxanthine.

The clear conclusion from these results is that PfNT1 encodes the high affinity hypoxanthine/adenosine transporter. This conclusion is somewhat at odds with the reports of PfNT1 as a relatively low affinity transporter when expressed in Xenopus laevis oocytes $[8,9,11]$. However, these previous reports differ substantially from each other, producing adenosine $\mathrm{K}_{\mathrm{m}}$ values of $320 \mu \mathrm{M}, 13.2 \mu \mathrm{M}$ and $1.86 \mathrm{mM}$, respectively. It may be that the Xenopus expression system produces ambiguous results when expressing some Plasmodium transporters, possibly as a result of the extremely high A+T content of the P. falciparum genome [41]; PfNT1 is $72 \% \mathrm{~A}+\mathrm{T}$. This would also explain the reported difficulties of expressing other P. falciparum ENT genes in this system [11]. Also, the Carter study used a different parasite clone than the Parker and Downie studies (W2 and 3D7, respectively), which had a single amino acid difference in their PfNT1 gene (Leu or Phe, respectively, at position 385). This could perhaps explain some of the discrepancy, especially since the Phe 385 polymorphism is unusual: in a multiple alignment of 28 protozoan ENT family genes plus the four human ENT sequences, the equivalent amino acid residue was conserved in so far as it was never aromatic, amide, charged, cysteine or proline. However, it is unlikely that the 3D7 clone of P. falciparum encodes a partly deficient PfNT1, as this clone was also used in the study reported by El Bissati et al that first suggested that PfNT1 is essential for growth on low purine concentrations [17]. We also used the 3D7 clone here and verified that its PfNT1 sequence was $100 \%$ identical to the entry in PlasmoDB (PF13_0252) and to the sequence reported by Parker et al. [8].

\section{A new model for purine salvage by $P$. falciparum.}

Our results, establishing a central role for a high affinity hypoxanthine transporter in the purine salvage of Plasmodium falciparum, agree very well with the early studies of purine salvage in other Plasmodium species, which describe a transport system for hypoxanthine with secondary capacity for purine nucleosides and a separate uptake system for adenine [1]. It is also consistent with the current understanding that purine nucleotide synthesis in Plasmodium spp. is overwhelmingly

460 nucleoside kinases $[4,5,42]$ and they do not seem to encode an adenosine kinase in 
461 their genome [35,36]. Furthermore, it brings purine uptake in P. falciparum very close 462 to purine transport activities reported for other protozoa, which typically display $\mathrm{K}_{\mathrm{m}}$ 463 values in the $0.2-5 \mu \mathrm{M}$ range for their substrates [1]. Earlier proposals that $P$. 464 falciparum may rely exclusively on low affinity purine transporters seemed hard to 465 reconcile with a free concentration of purine nucleosides and bases in the infected 466 erythrocyte that is presumably at best in the low micromolar range. Both the hENT1 467 nucleoside [43] and hFNT1 nucleobase [27] transporters of human erythrocytes are 468 equilibrative, making it impossible for the free concentrations of substrates to exceed 469 those in plasma. Nor is it likely that purine concentrations are much higher at the 470 parasite plasma membrane, as the parasitophorous vacuole membrane is freely 471 permeable to such low molecular weight solutes [30].

472 However, at adenosine concentrations that saturate the high affinity PfNT1 473 transporter, a very rapid and saturable nucleoside transport activity, PfLAAT, was 474 observed. Our transport experiments with $\triangle P f n t 1^{G U}$ prove that this is indeed a 475 separate transporter from PfNT1. We conclude that $P$. falciparum trophozoites 476 express both a high affinity purine nucleobase/nucleoside transporter and a low 477 affinity/high capacity adenosine transporter in addition to a saturable transport system 478 for $\left[{ }^{3} \mathrm{H}\right]$-adenine. The $\mathrm{K}_{\mathrm{m}}$ value of $\sim 200 \mu \mathrm{M}$ for PfLAAT rules out the possibility that 479 it might be identical to the high affinity adenine transporter PfADET1 ( $\mathrm{K}_{\mathrm{i}}$ (adenosine) $480=2.0 \mu \mathrm{M})$ and equally appears to rule out that it is identical to the low affinity adenine 481 transport activity PfADET2 that is almost insensitive to adenosine. However, this 482 awaits formal proof, consisting of experiments with genetic deletion lines of the genes 483 484 485 486 encoding these purine transporters - which are in progress.

Thus a model arises (depicted in Figure 6) that closely mirrors the model for purine transport in the only other apicomplexan parasite for which purine transport has been studied in detail. Toxoplasma gondii is known to express a low affinity adenosine transporter TgAT1, with a $\mathrm{K}_{\mathrm{m}}$ value of $\sim 110 \mu \mathrm{M}[13,44,45]$, as well as a high affinity transporter $\operatorname{TgAT} 2\left(\mathrm{~K}_{\mathrm{m}}\right.$ is $0.49 \mu \mathrm{M}$ for adenosine and $0.77 \mu \mathrm{M}$ for inosine) [13]. The main difference between purine salvage in the two apicomplexan species is that, unlike $P$. falciparum, T. gondii expresses separate high affinity transporters for purine nucleosides (TgAT2) and oxopurine nucleobases (TgNBT1). Like PfNT1, TgNBT1 does not transport adenine [13]. 
493

494

495

496

497

498

499

500

501

502

503

504

505

506

507

\section{Acknowledgements}

NBQ was supported by a Getfund studentship of the Government of Ghana and this work is submitted as partial fulfilment of the requirement for the degree of $\mathrm{PhD}$. DDS was supported by the European Commission (SIGMAL and ANTIMAL projects). PGB is supported by the MRC and the BBSRC. The authors are grateful to Dr Dan Brown, Dr Kathleen Too and Dr David Loakes of the MRC in Cambridge, UK, for the supply of antiplasmodial purine analogues and helpful discussions, and to the Glasgow and West of Scotland Blood Transfusion Service for the provision of human blood and serum.

Correspondence to: Harry P. de Koning, Institute of Biomedical and Life Sciences, Division of Infection and Immunity, University of Glasgow, 120 University Avenue, Glasgow G12 8TA, UK; e-mail: H.de-Koning@bio.gla.ac.uk. 


\section{References}

1. De Koning, H. P., Bridges, D. J. and Burchmore, R. (2005) Purine and pyrimidine transport in pathogenic protozoa: from biology to therapy. FEMS Microbiol. Rev. 29, 987-1020

2. Tracy, S. M. and Sherman, I. W. (1972) Purine uptake and utilization by the avian malaria parasite Plasmodium lophurae. J. Protozool. 19, 541-549

3. Hansen, B. D., Sleeman, H. and Pappas, P. W. (1980) Purine base and nucleoside uptake in Plasmodium berghei and host erythrocytes. J. Parasitol. 66, 205-212

4. Reyes, P., Rathod, P. K., Sanchez, D. J., Mrema, J. E. K., Rieckmann, K. H. and Heidrich, H. G. (1982) Enzymes of purine and pyrimidine metabolism from the human malaria parasite Plasmodium falciparum. Mol. Biochem. Parasitol. 5, 275-290

5. Manandhar, M. S. P. and Van Dyke, K. (1975) Detailed purine salvage metabolism in and outside the free malarial parasite. Exp. Parasitol. 37, 138146

6. Berman, P. A., Human, L. and Freese, J. A. (1991) Xanthine oxidase inhibits growth of Plasmodium falciparum in human erythrocytes in vitro. J. Clin. Invest. 88, 1848-1855

7. Penny, J. I., Hall, S. T., Woodrow, C. J., Cowan, G. M., Gero, A. M. and Krishna, S. (1998) Expression of substrate-specific transporters encoded by Plasmodium falciparum in Xenopus laevis oocytes. Mol. Biochem. Parasitol. 93, 81-89

8. Parker, M. D., Hyde, R. J., Yao, S. Y. M., McRobert, L., Cass, C. E., Young, J. D., McConkey, G. A. and Baldwin, S. A. (2000) Identification of a nucleoside/nucleobase transporter from Plasmodium falciparum, a novel target for antimalarial chemotherapy. Biochem. J. 349, 67-75

9. Carter, N. S., Ben Mamoun, C., Liu, W., Silva, E. O., Landfear, S. M., Goldberg, D. E. and Ullman, B. (2000) Isolation and functional characterization of the PfNT1 nucleoside transporter gene from Plasmodium falciparum. J. Biol. Chem. 275, 10683-10691

10. Rager, N., Ben Mamoun, C., Carter, N. S., Goldberg, D. E. and Ullman, B. (2001) Localization of the Plasmodium falciparum PfNT1 nucleoside transporter to the parasite plasma membrane. J. Biol. Chem. 276, 41095-41099

11. Downie, M. J., Saliba, K. J., Howitt, S. M., Bröer, S. and Kirk, K. Transport of nucleosides across the Plasmodium falciparum parasite plasma membrane has characteristics of PfENT1. Mol. Microbiol. 60, 738-748

12. Ghosh, M. and Mukherjee, T. (2000) Stage-specific development of a novel adenosine transporter in Leishmania donovani amastigotes. Mol. Biochem. Parasitol. 108, 93-99

13. De Koning, H. P., Al-Salabi, M. I., Cohen, A., Coombs, G. and Wastling, J. M. (2003) Identification and characterization of high affinity purine nucleoside and nucleobase transporters in Toxoplasma gondii. Int. J. Parasitol. 33, $821-831$

14. Al-Salabi, M. I. and De Koning HP. (2005) Purine nucleobase transport in amastigotes of Leishmania mexicana: involvement in allopurinol uptake. Antimicrob. Ag. Chemother. 49, 3682-3689

15. Carter, N. S. and Fairlamb, A. H. (1993) Arsenical-resistant trypanosomes lack an unusual adenosine transporter. Nature 361, 173-176 
16. De Koning, H. P. and Jarvis, S. M. (1997) Purine nucleobase transport in bloodstream forms of Trypanosoma brucei brucei is mediated by two novel transporters. Mol. Biochem. Parasitol. 89, 245-258

17. El Bissati, K., Zufferey, R., Wittola, W. H., Carter, N. S., Ullman, B. and Ben Mamoun, C. (2006) The plasma membrane permease PfNT1 is essential for purine salvage in the human malaria parasite Plasmodium falciparum. Proc. Natl. Acad. Sci. U.S.A. 103, 9286-9291

18. Martin, R. E., Henry, R. I., Abbey, J. L., Clements, J. D. and Kirk, K. (2005) The 'permeome' of the malaria parasite: an overview of the membrane transport proteins of Plasmodium falciparum. Genome Biol. 6, R26

19. Trager, W. and Jensen, J. B. (1976) Human malaria parasites in continuous culture. Science 193, 673-675

20. Lambros, C. and Vanderberg, J. P. (1979) Synchronization of Plasmodium falciparum erythrocytic stages in culture. J. Parasitol. 65, 418-420

21. Stead, A. M. W., Bray, P. G., De Koning, H. P., Elford, B. C., Stocks P. A. and Ward, S. A. (2001) Diamidine Compounds: Selective uptake and targeting in Plasmodium falciparum. Mol. Pharmacol. 59, 1298-1306

22. Beaumelle, B. D., Vial, H. J. and Phillippot, J. R. (1987) Reevaluation, using marker enzymes, of the ability of saponin and ammonium chloride to free Plasmodium from infected erythrocytes. J. Parasitol. 73, 743-748.

23. Saliba, K. J. and Kirk, K. (1999) $\mathrm{pH}$ regulation in the intracellular malaria parasite, Plasmodium falciparum. $\mathrm{H}^{+}$extrusion via $\mathrm{H}^{+}$-ATPase. J. Biol. Chem. 274, 33213-33219

24. Allen, R. J. W. and Kirk, K. (2004) The membrane potential of the intraerythrocytic malaria parasite Plasmodium falciparum. J. Biol. Chem. 279, 11264-11272

25. De Koning, H. P, Watson, C.J. and Jarvis, S.M. (1998) Characterisation of a nucleoside/proton symporter in procyclic Trypanosoma brucei brucei. J. Biol. Chem. 273, 9486-9494

26. Al-Salabi, M. I., Wallace, L. J. M. and De Koning, H. P. (2003) A Leishmania major nucleobase transporter responsible for allopurinol uptake is a functional homologue of the Trypanosoma brucei H2 transporter. Mol. Pharmacol. 63, 814-820

27. Wallace, L. J. M., Candlish, D. and De Koning, H. P. (2002) Different substrate recognition motifs of human and trypanosome nucleobase transporters: selective uptake of purine antimetabolites. J. Biol. Chem. 277, 26149-26156

28. Saliba, K. J., Horner, H. A. and Kirk, K. (1998) Transport and metabolism of the essential vitamin pantothenic acid in human erythrocytes infected with the malaria parasite Plasmodium falciparum. J. Biol. Chem. 273, 10190-10195

29. Sidhu, A. B., Valderramos, S. G. and Fidock, D. A. (2005) Pfmdr1 mutations contribute to quinine resistance and enhance mefloquine and artemisinin sensitivity in Plasmodium falciparum. Mol. Microbiol. 57, 913-926

30. Desai, S. A., Krogstad, D. J. and McCleskey, E. W. (1993) A nutrientpermeable channel on the intraerythrocytic malaria parasite. Nature 362, 643646

31. Stein, A., Vaseduvan, G., Carter, N. S., Ullman, B., Landfear, S. M., Kavanaugh, M. P. (2003) Equilibrative nucleoside transporter family members from Leishmania. J. Biol. Chem. 278, 35127-35134 
606

607

608

609

610

611

612

613

614

615

616

617

618

619

620

621

622

623

624

625

626

627

628

629

630

631

632

633

634

635

636

637

638

639

640

641

642

643

644

645

646

647

648

649

650

651

652

653

654

655

32. Gutteridge, W. E. and Trigg. P. I. (1970) Incorporation of radioactive precursors into DNA and RNA of Plasmodium knowlesi in vitro. J. Protozool. 17, 89-96

33. Too, K., Brown, D. M., Bongard, E., Yardley, V., Vivas, L. and Loakes, D. (2007) Anti-malarial activity of N6-modified purine analogs. Bioorg. Med. Chem. 15, 5551-5562

34. Goudela, S., Karatza, P., Koukaki, M., Frilingos, S. and Diallinas, G. (2005) Comparative substrate recognition by bacterial and fungal purine transporters of the NAT/NCS2 family. Mol. Membr. Biol. 22, 263-275

35. Ting, L. M., Shi, W., Lewandowicz, A., Singh, V., Mwakingwe, A., Birck, M. R., Ringia, E. A., Bench, G., Madrid, D. C., Tyler, P. C., Evans, G. B., Furneaux, R. H., Schramm, V. L. and Kim, K. (2005) Targeting a novel Plasmodium falciparum purine recycling pathway with specific immucillins. J. Biol. Chem. 280, 9547-9554

36. Chaudhary, K., Darling, J. A., Fohl, L. M., Sullivan, W. J., Donald, R. G., Pfefferkorn, E. R., Ullman, B. and Roos, D. S. (2004) Purine salvage pathways in the apicomplexan parasite Toxoplasma gondii. J. Biol. Chem. 279, 31221-31227

37. Walter, R. D. and Königk, E. (1974) hypoxanthine-guanine phosphoribosyltransferase and adenine phosphoribosyltransferase from Plasmodium chabaudi; purification and properties. Tropenmed. Parasitol. 25, 227-235

38. Queen, S. A., Vander Jagt, D. L. and Reyes, P. (1989) Characterisation of adenine phosphoribosyltransferase from the human malaria parasite, Plasmodium falciparum. Biochim. Biophys. Acta 996, 160-165

39. Geary, T. G., Divo, A. A., Bonanni, L. C. and Jensen, J. B. (1985) Nutritional requirements of Plasmodium falciparum in culture. III. Further observations on essential nutrients and antimetabolites. J. Protozool. 32, 608-613

40. Van Dyke, K. (1975) Comparison of tritiated hypoxanthine, adenine and adenosine for purine salvage incorporation into nucleic acids of the malarial parasite, Plasmodium falciparum. Tropenmed. Parasitol. 26, 232-238

41. Gardner, M. J., Hall, N., Fung, E., White, O., Berriman, M., Hyman, R.W., Carlton, J. M., Pain, A., Nelson, K. E., Bowman, S., Paulsen, I. T., James, K., Eisen, J. A., Rutherford, K., Salzberg, S. L., Craig, A., Kyes, S., Chan, M. S., Nene, V., Shallom, S. J., Suh, B., Peterson, J., Angiuoli, S., Pertea, M., Allen, J., Selengut, J., Haft, D., Mather, M. W., Vaidya, A. B., Martin, D. M., Fairlamb, A. H., Fraunholz, M. J., Roos, D. S., Ralph, S. A., McFadden, G. I., Cummings, L. M., Subramanian, G. M., Mungall, C., Venter, J. C., Carucci, D. J., Hoffman, S. L., Newbold, C., Davis, R. W., Fraser, C. M. and Barrell, B. (2002) Genome sequence of the human malaria parasite Plasmodium falciparum. Nature 419, 498-511

42. Berens, R. L., Krug, E. C. and Marr, J. J. (1995) Purine and Pyrimidine Metabolism. In Biochemistry and Molecular Biology of Parasites (Marr, J. J. and Müller, M., eds.), pp. 89-117, New York, Academic Press

43. Plagemann, P. G. W., Wohlhueter, R. M. and Woffendin C. (1988) Nucleoside and nucleobase transport in animal cells. Biochim. Biophys. Acta 947, 405443

44. Schwab, J. C., Afifi Afifi, M., Pizzorno, G., Handschumacher, R. E. and Joiner, K. A. (1995) Toxoplasma gondii tachyzoites possess an unusual plasma membrane adenosine transporter. Mol. Biochem. Parasitol. 70, 59-69 
656

657

658

659
45. Chiang, C.-W., Carter, N., Sullivan, W. J., Donald, R. G., Roos, D. S., Naguib, F. N., El Kouni, M. H., Ullman, B. and Wilson, C. M. (1999) The adenosine transporter of Toxoplasma gondii; identification by insertional mutagenesis, cloning, and recombinant expression. J. Biol. Chem. 274, 35255-35261 
660 Figure 1. Hypoxanthine transport in saponin-isolated Plasmodium falciparum 661 trophozoites. (A) Uptake of $0.25 \mu \mathrm{M}\left[{ }^{3} \mathrm{H}\right]$-hypoxanthine (squares) and $0.10 \mu \mathrm{M}\left[{ }^{3} \mathrm{H}\right]$ 662 hypoxanthine (circles) into saponin-permeabilised $P$. falciparum-infected erythrocytes 663 in the presence (open symbols) or absence (filled symbols) of $1 \mathrm{mM}$ unlabelled 664 hypoxanthine at $20^{\circ} \mathrm{C}$. The correlation coefficients $\left(\mathrm{r}^{2}\right)$ were determined as 0.99 and 6650.98 for $0.25 \mu \mathrm{M}$ and $0.1 \mu \mathrm{M}$ radiolabel, respectively, by linear regression over the 666 first $120 \mathrm{~s}$. (B) Uptake of $\left.30 \mathrm{nM} \mathrm{[}{ }^{3} \mathrm{H}\right]$-hypoxanthine in the presence or absence of 667 various concentrations of unlabelled hypoxanthine $(\square)$, adenosine $(\bullet)$ or JA32 $(\Delta)$. 668 Uptake rates are presented as percentage of no-inhibitor controls and combined from 669 two experiments with 100\% values of 0.013 (adenosine and JA32) and 0.033 670 pmol $\left(10^{7} \text { cells }\right)^{-1} \mathrm{~s}^{-1}$ (hypoxanthine), respectively. Inset: conversion of hypoxanthine inhibition data to Michaelis-Menten plot for determination of $K_{m}$ and $V_{\text {max }}$. Representative experiments are shown, conducted in triplicate. Error bars indicate SEM

Figure 2. Uptake of low concentrations of $\left[{ }^{3} \mathbf{H}\right]$-adenosine in isolated Plasmodium falciparum trophozoites. Transport of $0.25 \mu \mathrm{M}\left[{ }^{3} \mathrm{H}\right]$-adenosine was measured over $30 \mathrm{~s}$ in the presence or absence of various concentrations of unlabelled adenosine ( $\square$ ), adenine $(\boldsymbol{\Delta})$ and hypoxanthine $(\bullet)$. Inset: conversion of the adenosine inhibition data to a Michaelis-Menten plot. The adenine $\mathrm{IC}_{50}$ value was obtained by extrapolation to $100 \%$ inhibition. Representative experiments performed in triplicate are shown; error bars represent SEM.

Figure 3. Characterization of a high affinity adenine transporter in $\boldsymbol{P}$. falciparum trophozoites. (A) Transport of $0.05 \mu \mathrm{M}\left[{ }^{3} \mathrm{H}\right]$-adenine over $240 \mathrm{~s}$, in the presence (O) or absence ( $\mathbf{a})$ of $1 \mathrm{mM}$ unlabelled adenine. In the absence of inhibitor the transport rate was $3.9 \pm 0.2 \times 10^{-5} \mathrm{pmol}\left(10^{7} \text { cells }\right)^{-1} \mathrm{~s}^{-1}$ as calculated by linear regression $\left(\mathrm{r}^{2}=\right.$ 0.98). At $240 \mathrm{~s}$, uptake was inhibited $70 \%$ by $1 \mathrm{mM}$ adenine. (B) Transport of 0.05 $\mu \mathrm{M}\left[{ }^{3} \mathrm{H}\right]$-adenine was inhibited by increasing concentrations of unlabelled adenine $(\mathrm{O})$ or adenosine ( $\mathbf{\square})$. Adenine uptake was expressed as \% of control because two different experiments were combined, with no-inhibitor values of $2.4 \times 10^{-4}$ and $1.5 \times 10^{-4}$ pmol $\left(10^{7} \text { cells }\right)^{-1} \mathrm{~s}^{-1}$. Inset: conversion of the inhibition data to a Michaelis-Menten plot, yielding a $\mathrm{K}_{\mathrm{m}}$ value of $0.12 \mu \mathrm{M}$ for this experiment. Units of uptake were pmol $\left(10^{7} \text { cells }\right)^{-1} \mathrm{~s}^{-1}$. Error bars represent SEM.

Figure 4. Low affinity transport of adenosine in saponin-isolated Plasmodium falciparum trophozoites. Transport of $25 \mu \mathrm{M}\left[{ }^{3} \mathrm{H}\right]$-adenosine was determined over a three second interval at $6{ }^{\circ} \mathrm{C}$, in the presence of various concentrations of unlabelled adenosine as indicated. Inset: conversion to a Michaelis-Menten plot. Error bars are SEM; where not shown fall within the symbol.

Figure 5. Purine transport in $P$. falciparum trophozoites lacking PfNT1. Transport in $\triangle P F N T 1^{\mathrm{GU}}$ is indicated with open squares and in control 3D7 parasites with filled circles. (A) $25 \mu \mathrm{M}\left[{ }^{3} \mathrm{H}\right]$-adenosine at $6{ }^{\circ} \mathrm{C}$. (B) $0.25\left[{ }^{3} \mathrm{H}\right]$-adenosine at $22{ }^{\circ} \mathrm{C}$. (C) 0.4 $\mu \mathrm{M}\left[{ }^{3} \mathrm{H}\right]$-hypoxanthine at $22{ }^{\circ} \mathrm{C}$. (D). $1 \mu \mathrm{M}\left[{ }^{3} \mathrm{H}\right]$-adenine at $22{ }^{\circ} \mathrm{C}$. Insets display the linear phase of uptake $\left(\mathrm{r}^{2}=0.99\right.$ for $\triangle P f N T 1^{\mathrm{GU}}$ and 0.98 for control 3D7).

Figure 6. Model of purine uptake into intraerythrocytic $P$. falciparum trophozoites. Double-headed arrows indicate presumed equilibrative transport, 
709 whereas the single headed arrow of PfNT1 indicates possible active transport. 710 However, the assignment of active or equilibrative transport is speculative and was 711 not investigated in the current study. hFNT1 and hENT1 are endogenous to the human 712 erythrocyte whereas the origin of the NPP is unknown. The thickness of arrows for 713 the $P$. falciparum transporters is meant to convey the relative flux of purines. NPP, 714 New Permeation Pathways; PV, Parasitophorous vacuole; IEC, infected erythrocyte 715 cytoplasm; Pf, Plasmodium falciparum. 
716 Table 1. Profile of purine transport in P. falciparum trophozoites.

717

\begin{tabular}{|c|c|c|c|c|c|c|c|c|}
\hline & \multicolumn{2}{|c|}{$\begin{array}{c}\text { High affinity }\left[{ }^{3} \mathrm{H}\right]- \\
\text { hypoxanthine uptake } \\
(\mathrm{PfNT} 1)\end{array}$} & \multicolumn{2}{|l|}{$\begin{array}{l}\text { High affinity }\left[{ }^{3} \mathrm{H}\right]- \\
\text { adenosine uptake } \\
\text { (PfNT1) }\end{array}$} & \multicolumn{2}{|c|}{$\begin{array}{l}\text { Low affinity }\left[{ }^{3} \mathrm{H}\right]- \\
\text { adenosine uptake } \\
\text { (PfLAAT) }\end{array}$} & \multicolumn{2}{|c|}{$\begin{array}{c}\text { High affinity }\left[{ }^{3} \mathrm{H}\right]- \\
\text { adenine uptake } \\
\text { (PfADET } 1)\end{array}$} \\
\hline & $\begin{array}{c}\mathrm{K}_{\mathrm{i}} \text { or } \mathrm{K}_{\mathrm{m}} \text { value } \\
\left.\text { (at } 22^{\circ} \mathrm{C} ; \mu \mathrm{M}, \pm \mathrm{SEM}\right)\end{array}$ & $\mathrm{n}$ & $\begin{array}{c}\mathrm{K}_{\mathrm{i}} \text { or } \mathrm{K}_{\mathrm{m}} \text { value } \\
\text { (at } 22^{\circ} \mathrm{C} ; \mu \mathrm{M}, \pm \mathrm{SEM} \text { ) }\end{array}$ & $\mathrm{n}$ & $\begin{array}{c}\mathrm{K}_{\mathrm{i}} \text { or } \mathrm{K}_{\mathrm{m}} \text { value } \\
\text { (at } 6^{\circ} \mathrm{C} ; \mu \mathrm{M}, \\
\pm \mathrm{SEM})\end{array}$ & $\mathrm{n}$ & $\begin{array}{c}\mathrm{K}_{\mathrm{i}} \text { or } \mathrm{K}_{\mathrm{m}} \text { value } \\
\text { (at } 22^{\circ} \mathrm{C} ; \mu \mathrm{M}, \\
\pm \mathrm{SEM} \text { ) }\end{array}$ & $\mathrm{n}$ \\
\hline $\mathrm{V}_{\max }{ }^{(a)}$ & $0.36 \pm 0.12$ & 6 & $0.18 \pm 0.08$ & 3 & $0.19 \pm 0.03$ & 3 & $0.0004 \pm 0.0002$ & 3 \\
\hline $\mathrm{V}_{\max } / \mathrm{K}_{\mathrm{m}}$ & 1.1 & & 0.090 & & 0.00096 & 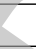 & 0.0019 & \\
\hline Hypoxanthine & $0.34 \pm 0.05$ & 6 & $0.75 \pm 0.18$ & 3 & ND & & $>1000$ & 3 \\
\hline Guanine & $0.11 \pm 0.01$ & 3 & ND & & $\mathrm{ND}$ & & $>50$ & 3 \\
\hline Inosine & $2.0 \pm 0.2$ & 3 & ND & & $\mathrm{ND}$ & & $>1000$ & 3 \\
\hline Adenosine & $4.0 \pm 0.67$ & 3 & $2.0 \pm 0.2$ & 3 & $197 \pm 20$ & 3 & $2.0 \pm 0.2$ & 3 \\
\hline Guanosine & $11.6 \pm 2.7$ & 3 & ND & & ND & & ND & \\
\hline Adenine & $>500$ & 3 & $240 \pm 70$ & 3 & ND & & $0.23 \pm 0.07$ & 3 \\
\hline
\end{tabular}

719 Values in bold are $K_{m}$ values obtained with radiolabelled substrate; other values are $K_{i}$ 720 values, obtained from dose-dependent inhibition of radiolabelled substrate. All values 721 were determined using non-linear regression from experiments in duplicate or 722 triplicate with a minimum of 8 points over the relevant range. Zero values were taken 723 to be radiolabel associated with the cell pellet in the presence of saturating 724 concentrations of unlabelled permeant. ${ }^{a}$ units for $V_{\max }$ are pmol $\left(10^{7} \text { cells }\right)^{-1} \mathrm{~s}^{-1}$. ND, 725 not determined. 
B Biochemical Journal Immediate Publication. Published on 11 Jan 2008 as manuscript BJ20071460

A
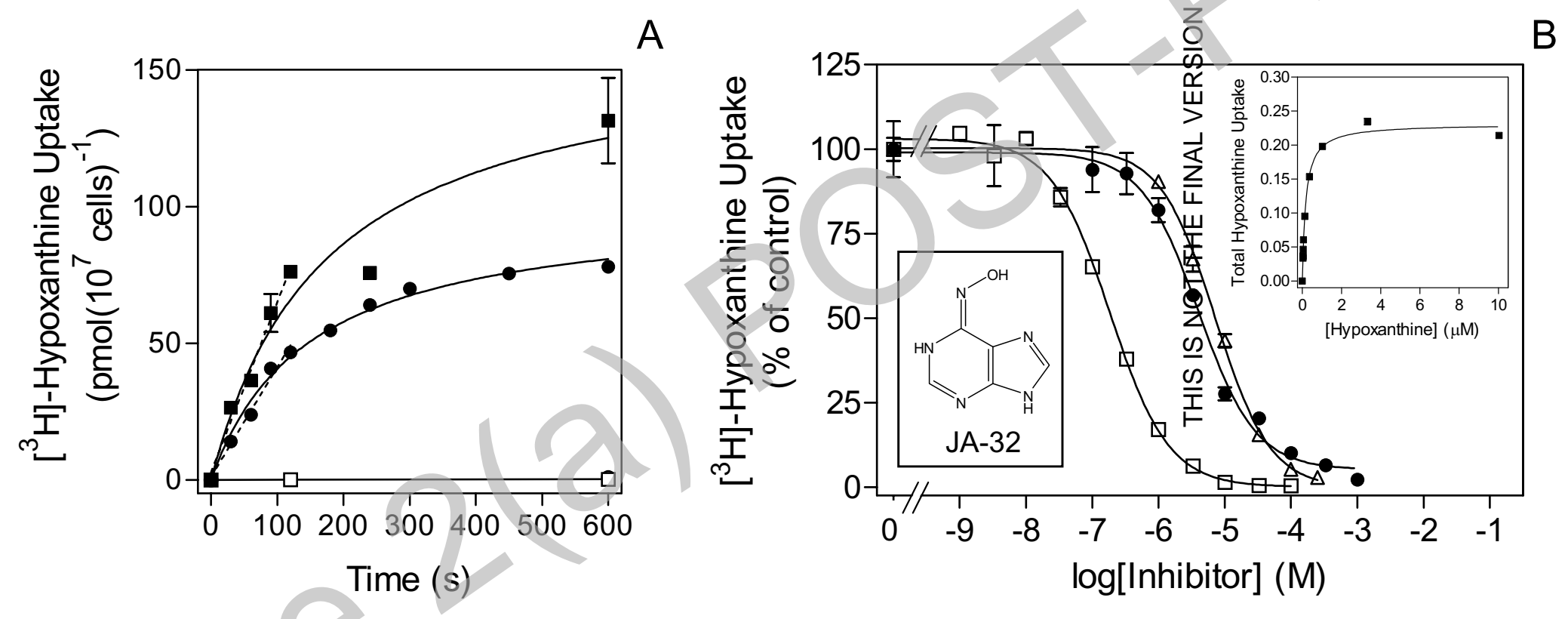


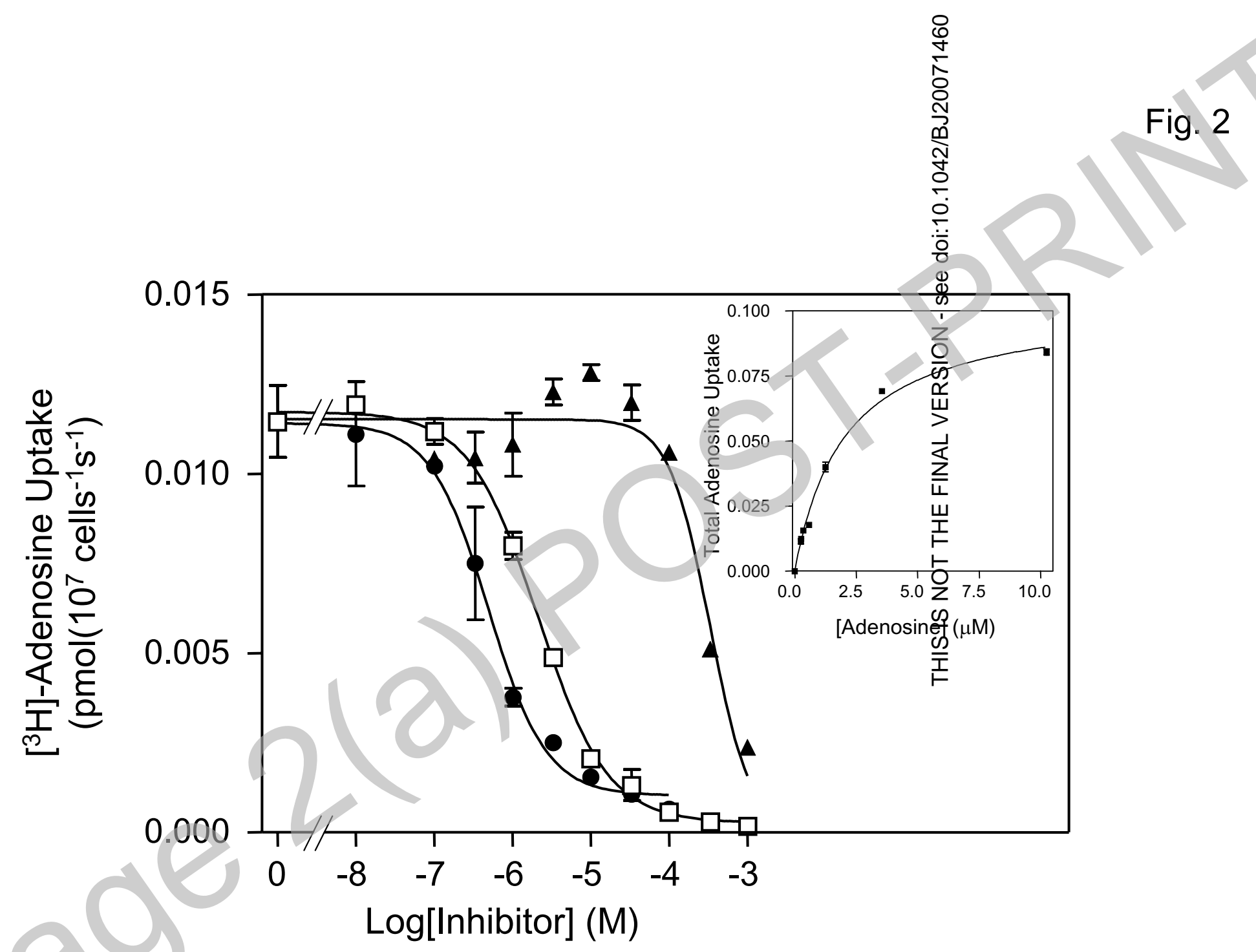




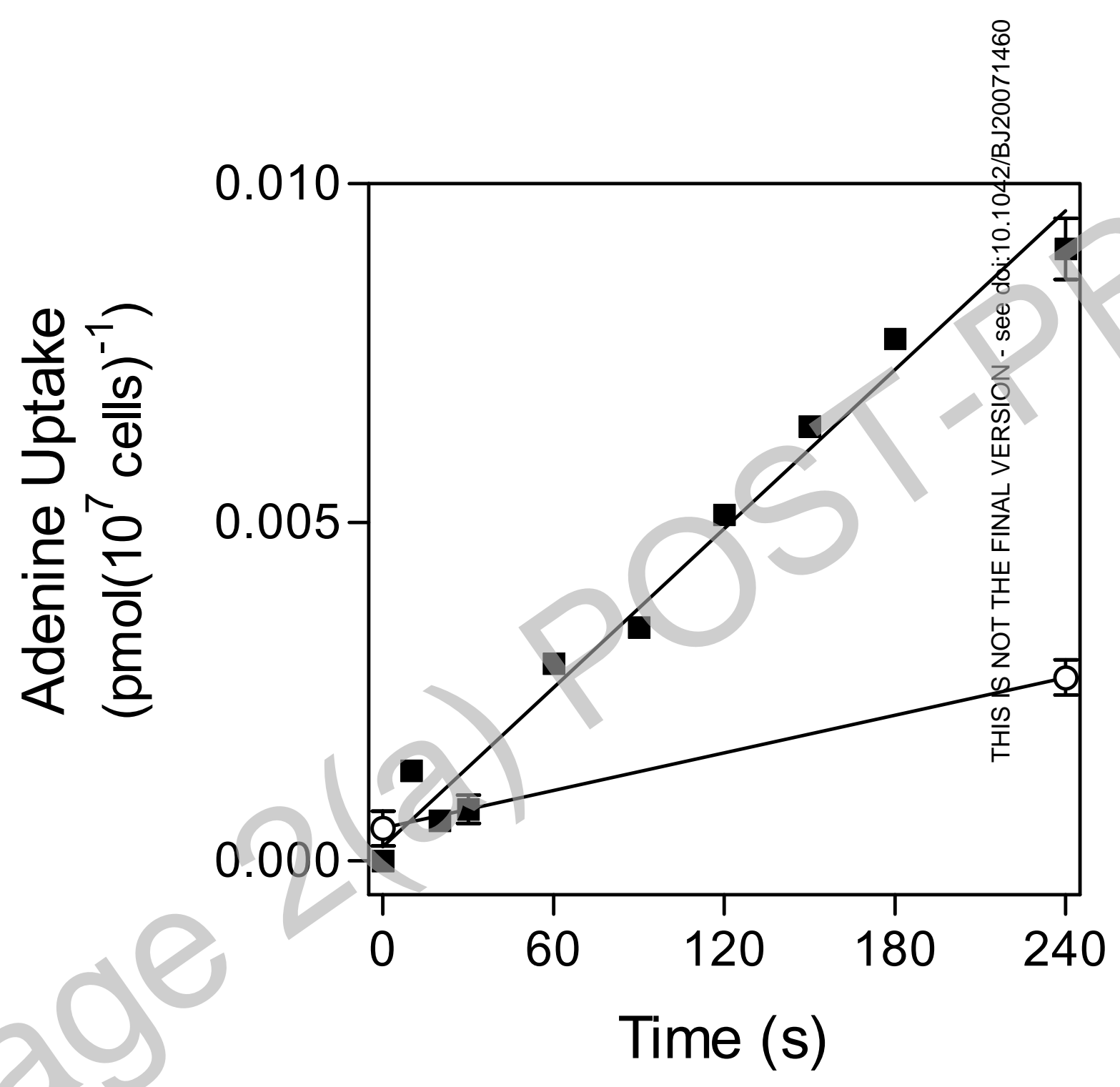

Fig. 3A 


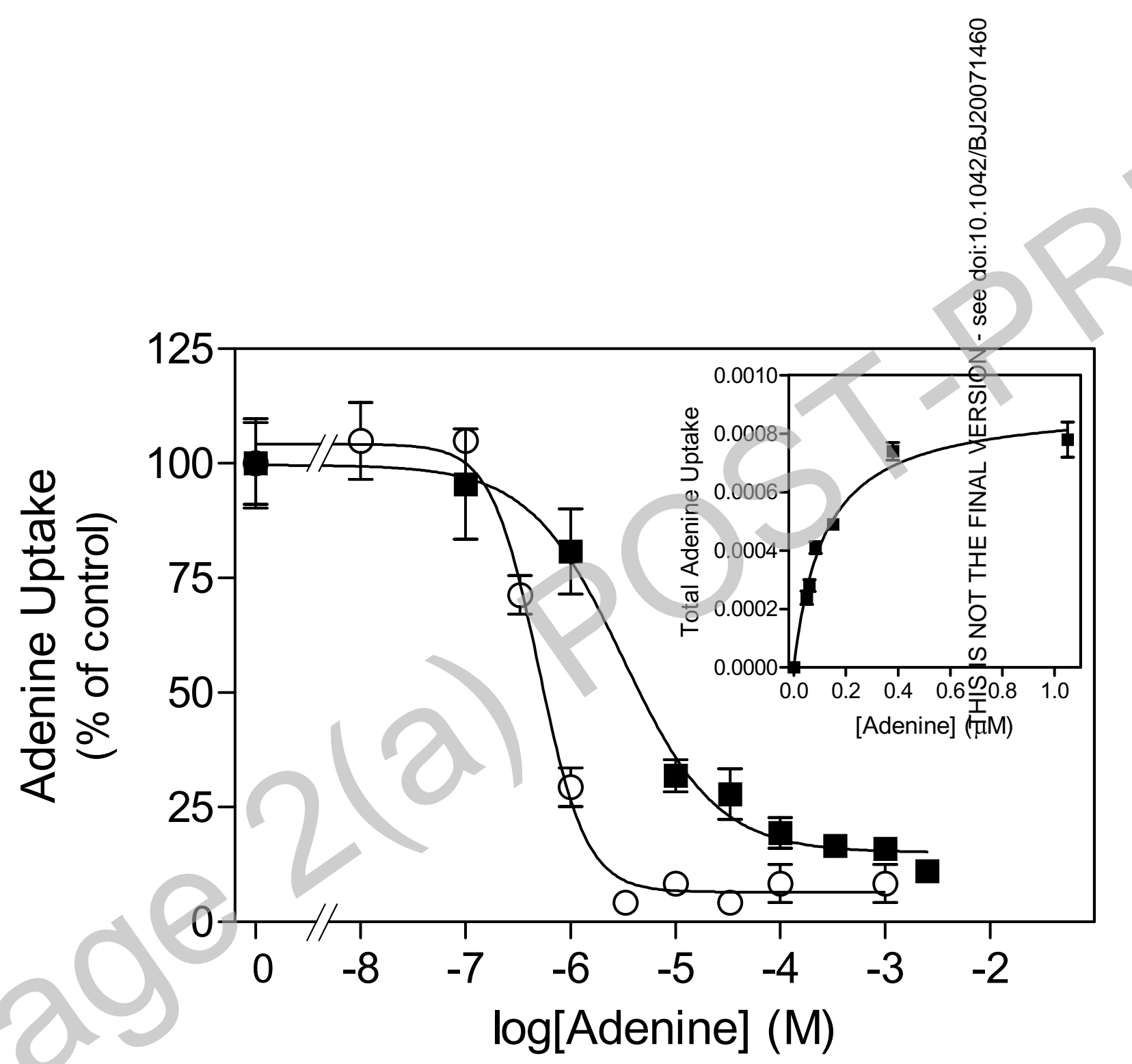

Fig. 3B 


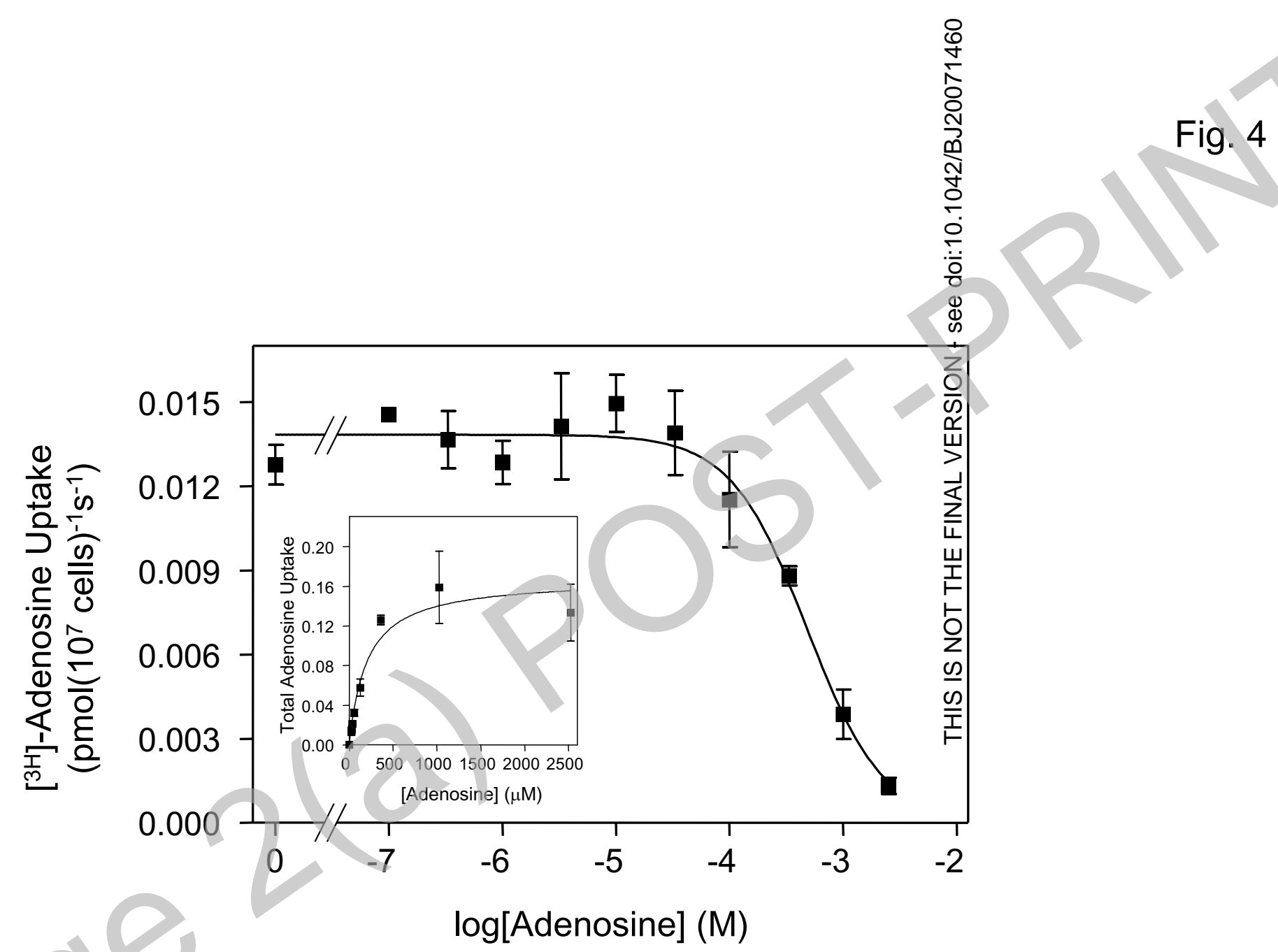




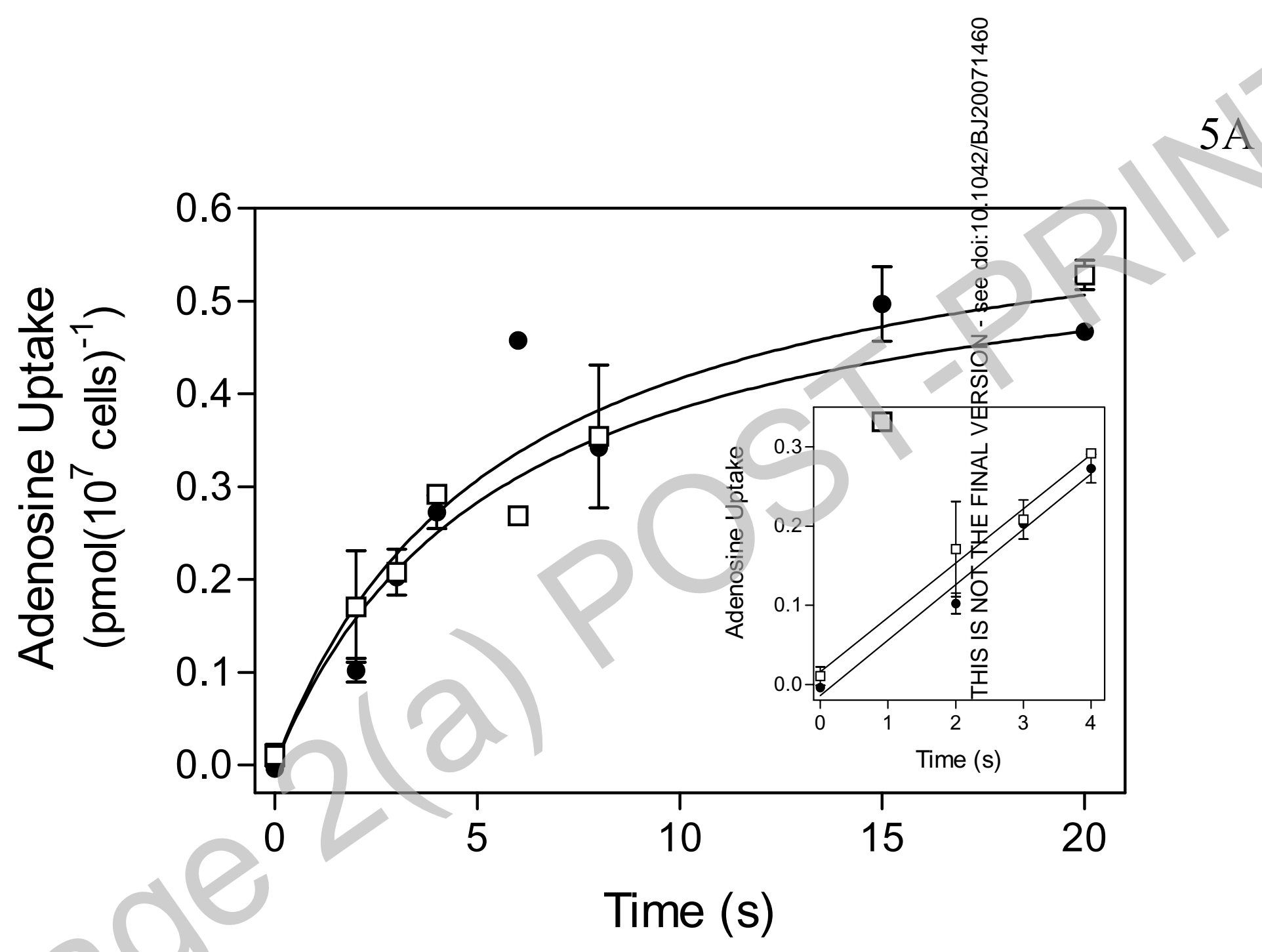




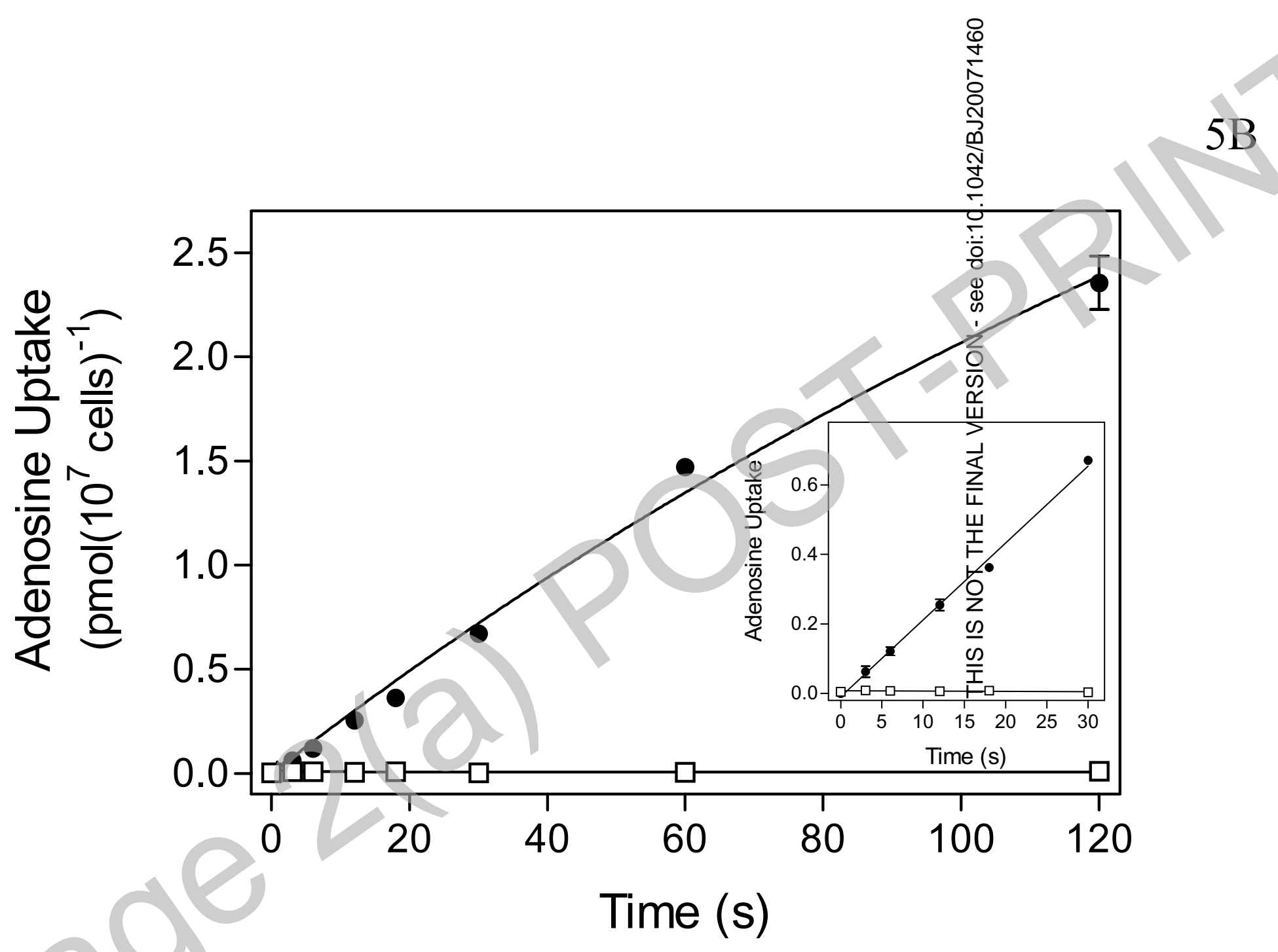




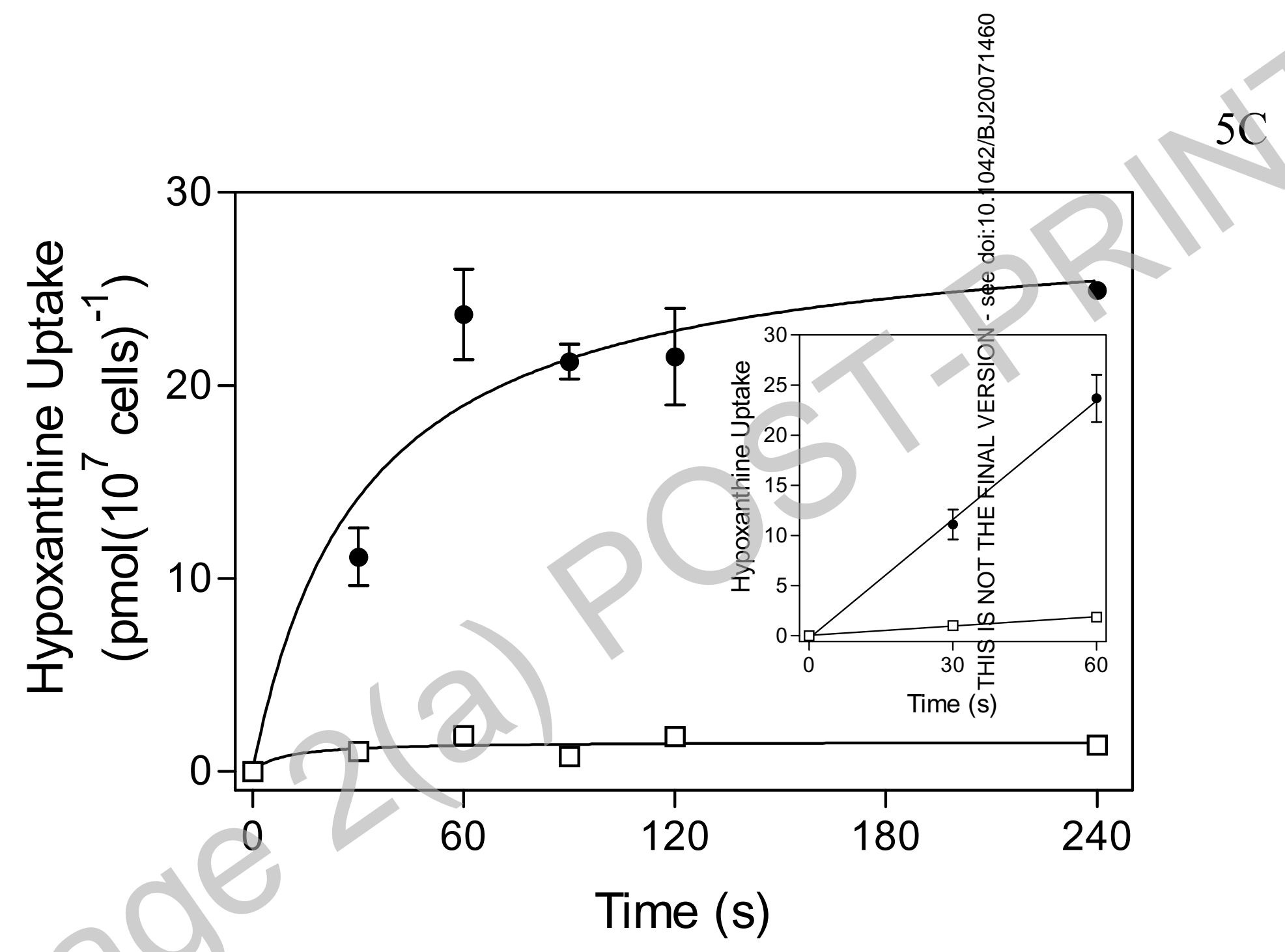




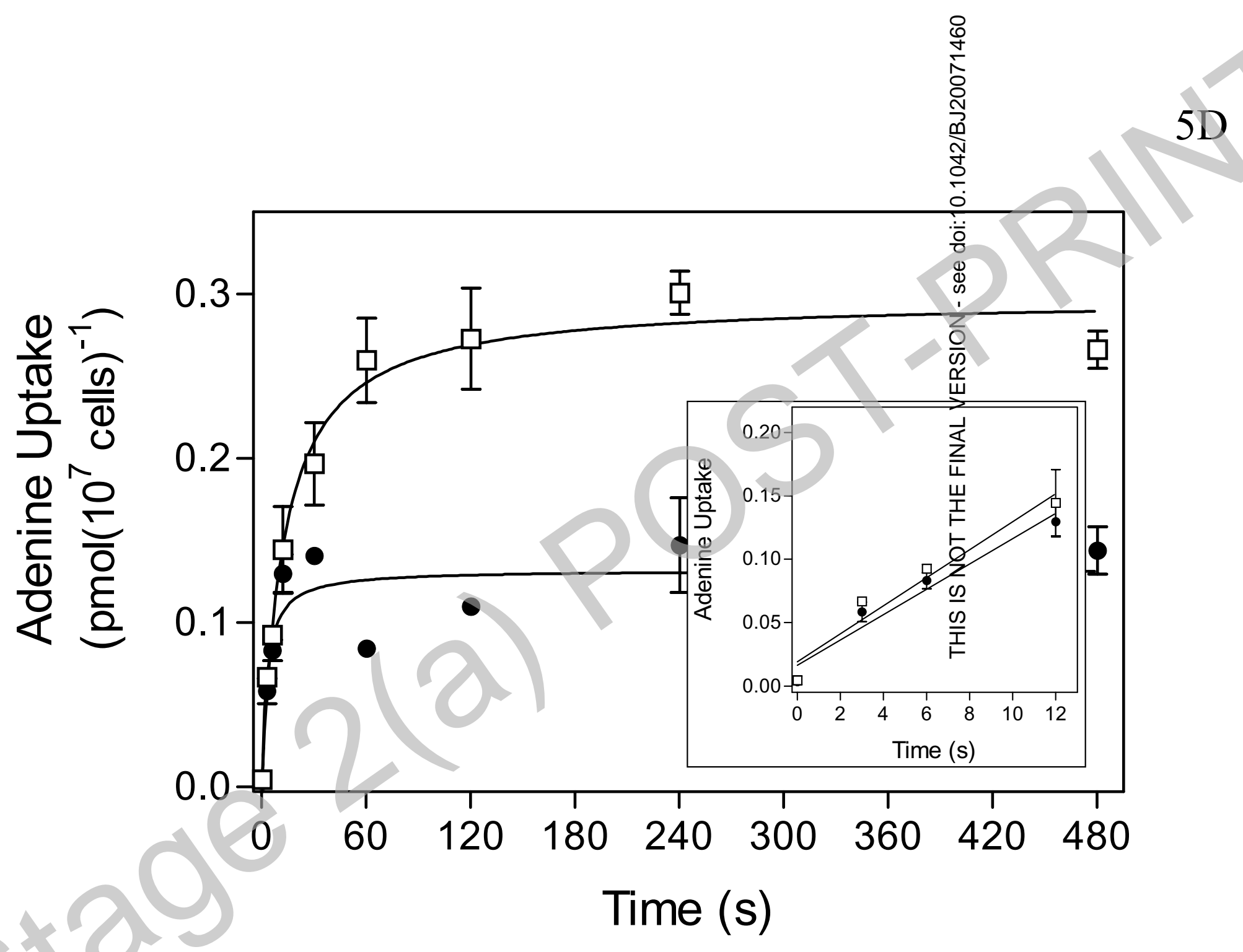




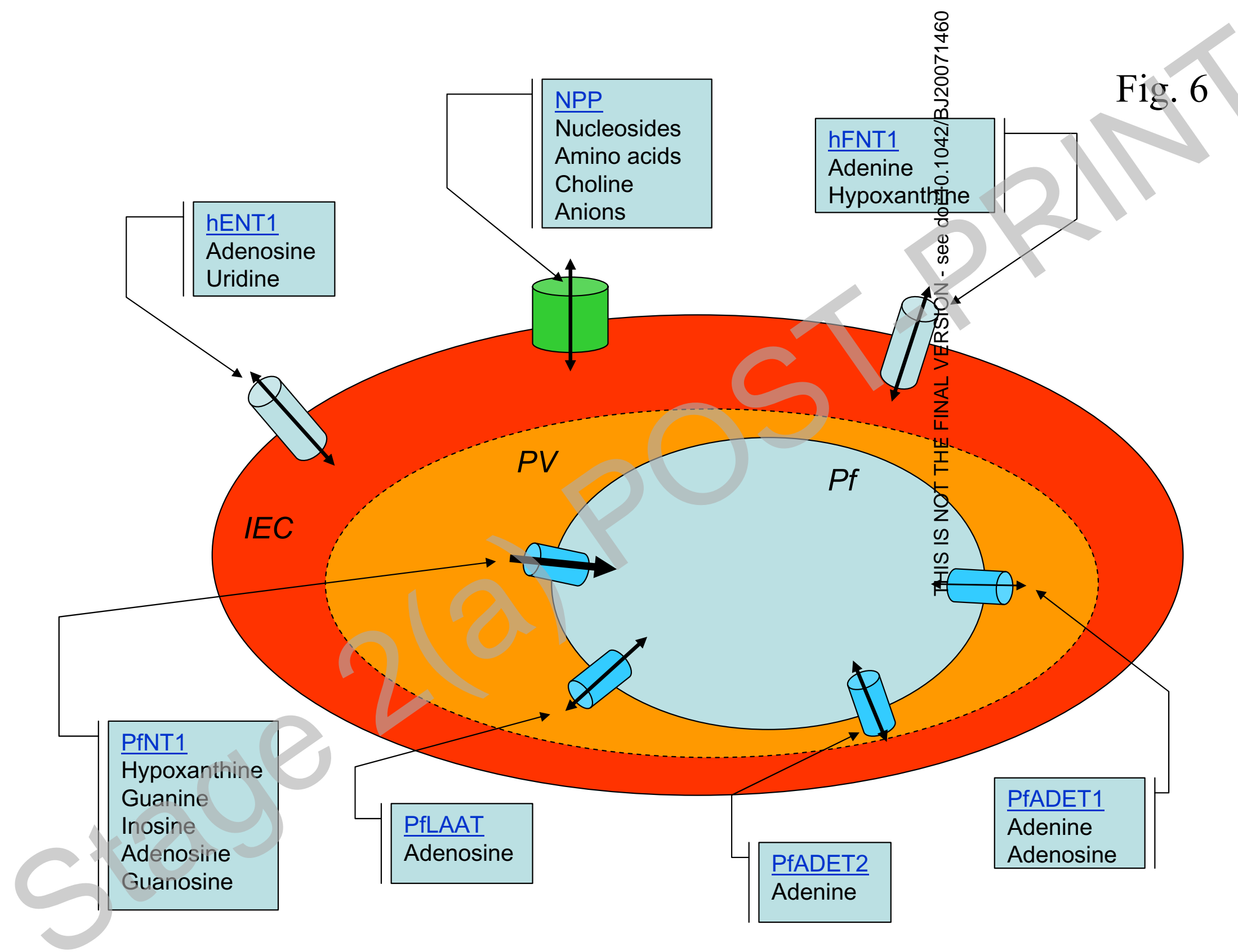

Licenced copy. Copying is not permitted, except with prior permission and as allowed by law. (c) 2008 The Authors Journal compilation (c) 2008 Biochemical Society 